\title{
Let's Get Vaccinated for Both Flu and COVID-19: On the World Flu Day 2021
}

\author{
George F. Gao ${ }^{1, *}$; William J. Liu ${ }^{1}$
}

This year marks the fourth World Flu Day on November 1. In 2018, on the occasion of centenary of the 1918 flu pandemic, the first World Flu Day was formally initiated and developed by leading influenza specialists in China and all over the world at a symposium in Shenzhen, China, with the theme to "Commemorate the Centenary of the 1918-19 Influenza Pandemic" (1). Scientists and representatives from different international associations and organizations, including the five World Health Organization (WHO) Collaborating Centers for Reference and Research on Influenza came together and advocated for raising public awareness of influenza, accelerating scientific innovation and international cooperation on influenza surveillance and basic research, and pushing for stronger global support on influenza prevention and control (2). The second and the third World Flu Day Symposia were held in Beijing with the themes as "Know Flu/Prevent Flu/Beat Flu" in 2019 and "Influenza Control and COVID-19 Pandemic Response" in 2020.

In the past century, humans had endured 5 influenza pandemics: "Spanish flu" (H1N1) in 1918, "Asian flu" (H2N2) in 1957, "Hong Kong flu" (H3N2) in 1968, and "Russian flu" (H1N1, "pseudopandemic") in 1977, and "Mexico Swine flu" (H1N1) in 2009 (3). With the emerging events of diverse human-infecting avian influenza viruses, i.e., $\mathrm{H} 5 \mathrm{~N} 1$, H5N6, H6N1, H7N9, H9N2, H10N8, H7N4, etc. in the recent decades, scientists estimated that the next pandemic may be caused by the influenza virus and the world seems to not be prepared for it. Meanwhile, a new respiratory tract infectious disease coronavirus disease 2019 (COVID-19) emerged in the end of 2019 and developed rapidly in the early months of 2020 as the first recognized pandemic caused by the coronavirus (4). Beyond all doubt, humans were not prepared for the pandemic and COVID-19 affected and even changed virtually everyone's lives (5). The relevant scientists and health workers all over the world have tried their best to understand and control the new disease (6). However, the etiology of COVID-19, severe acute respiratory syndrome (SARS-CoV-2; initially named 2019-NCIP and hCoV-19) is still wreaking havoc with the continuously emerging variants $(7)$. Thus, in the coming seasons of influenza, we are facing the complexity and challenge of influenza and COVID-19 cocirculation. Currently, promoting vaccination coverage is still the prioritized strategy to efficiently control the current COVID-19 pandemic and to prevent seasonal influenza. Thus, for the World Flu Day 2021, we advocate the theme as "Flu and COVID-19, Let's Get Vaccinated" this year.

From early 2020, the seasonal influenza activity has had a dramatic drop with the implementation of nonpharmaceutical interventions (NPIs) and behavioral changes to mitigate COVID-19 (8-10). The 2019-2020 seasonal influenza activity was significantly reduced compared with the previous seasons in China, the United States, and other countries, and the decreases in influenza virus infection were also associated with the timing of NPIs (9). In actuality, this relief situation of influenza was sustained in the following seasons and one influenza lineage, i.e. B/Yamagata, has not been isolated from April 2020 to August 2021 and seems to have possibly become extinct (11). NPIs implemented against COVID-19 played an unexpected extra role in this process, including use of individual protection, e.g., wearing masks, watching distance, washing hands (3-W), and restriction of personal movement, e.g., canceling mass gatherings, closing public entertainment venues, closing schools, restricting domestic and international travel, and issuing stay-at-home orders (12).

In spite of the low prevalence of seasonal influenza viruses among humans, an undercurrent of avian influenza viruses still whirls among poultry populations. Since the end of 2019, highly pathogenic $\mathrm{H} 5 \mathrm{Ny}$ avian influenza has frequently occurred in birds in Eurasia and Africa (13). Analyses of highly pathogenic avian influenza $\mathrm{H} 5$ viruses from poultry outbreaks and recent detections in migratory waterfowl across a wide Eurasian region revealed maintenance of A/H5 clade 2.3.4.4b, i.e., $\mathrm{H} 5 \mathrm{~N} 8, \mathrm{H} 5 \mathrm{~N} 5$, and $\mathrm{H} 5 \mathrm{~N} 1$, 
etc. (14), which raised a highly alarming threat to poultry production, veterinary disease control, and human public health. Especially in the spring of 2020, the 2.3.4.4b branch $\mathrm{H} 5 \mathrm{~N} 8$ avian influenza virus caused multiple outbreaks in Central and Eastern Europe, implying a new wave of highly pathogenic $\mathrm{H} 5 \mathrm{Ny}$ avian influenza in the broad area (15). A detailed genetic and biological analysis of avian influenza outbreaks in wild birds in China over the decade before 2019 found that 5 out of 10 highly pathogenic $\mathrm{H} 5 \mathrm{Ny}$ avian influenza could bind humantype receptors, all of which were from clade 2.3.4.4 (16). Human infection of clade 2.3.4.4b influenza A(H5N8) virus with 7 cases was reported at a poultry farm in Astrakhan, Russia in December 2020 (17). Before the end of 2020, a total of 26 laboratoryconfirmed cases of human infection with influenza $\mathrm{A}(\mathrm{H} 5 \mathrm{~N} 6)$ virus have been reported (18). However, in 2021 thus far, more than 20 sporadic human infections have been recorded in different provincial-level administrative divisions (19). All this evidence of human $\mathrm{H} 5 \mathrm{Ny}$ infections indicate a sustained spillover of avian influenza virus and deserve close attention.

The pandemic of COVID-19 brings unprecedented pressure and challenges to global public health and changes the landscape of influenza prevalence. In front of the complexity and unpredictability of the influenza epidemic and its co-circulation with COVID-19, the concerns for seasonal influenza among humans and the avian influenza among birds should not be reduced. Herein, on the occasion of the fourth World Flu Day, we would like to lift up our voice to bring the attention of the public to influenza. Public understanding of science plays a pivotal role in the implementation of disease control and prevention strategies (20-21). Historical lessons learnt from influenza and current experience obtained from COVID-19 should remain at the core of global efforts for pandemic preparedness. Commemorating World Flu Day together is not just a timely call for raising global awareness about this common and easily ignored disease, especially with the COVID-19 pandemic under the global spotlight, but it is also an important opportunity to advocate for the vaccination for the two pandemic-igniting viruses.

In this issue of the China CDC Weekly, we have reported the surveillance of influenza activity in the mainland of China in 2020-2021, with an intensity of activity lower than before COVID-19, but gradually increasing compared to 2020 (22); this issue also reported two human cases of H5N6 infection in 2021 in Guangxi Zhuang Autonomous Region, China, which provides evidence of a continuous threat to humans from $\mathrm{H} 5 \mathrm{Ny}$ avian influenza viruses (23). We also included a review article on continuous circulation, frequent gene reassortment, and mammalian adaptation of $\mathrm{H} 3$ avian influenza viruses in the past two decades in the mainland of China (24). A review on the Global Influenza Surveillance and Response System (GISRS) was also included (25), which summarized the existing WHO influenza surveillance systems that have been leveraged for global responses to COVID-19 since the beginning of the pandemic and addressed future challenges and plans.

doi: $10.46234 / \mathrm{ccdcw} 2021.227$

\# Corresponding author: George F. Gao, gaofu@chinacdc.cn.

${ }^{1}$ Chinese Center for Disease Control and Prevention, Beijing, China.

Submitted: October 28, 2021; Accepted: October 29, 2021

\section{REFERENCES}

1. The Lancet. World Flu Day: momentum from China for influenza control. Lancet 2018;392(10158):1600. http://dx.doi.org/10.1016/ S0140-6736(18)32770-3.

2. Liu WJ, Bi YH, Wang DY, Gao GF. On the centenary of the spanish flu: being prepared for the next pandemic. Virol Sin 2018;33(6):463 6. http://dx.doi.org/10.1007/s12250-018-0079-1.

3. Liu WJ, Wu Y, Bi YH, Shi WF, Wang DY, Shi Y, et al. Emerging $\mathrm{HxNy}$ influenza A viruses. Cold Spring Harb Perspect Med 2020a038406. http://dx.doi.org/10.1101/cshperspect.a038406.

4. Tan WJ, Zhao X, Ma XJ, Wang WL, Niu PH, Xu WB, et al. A novel coronavirus genome identified in a cluster of pneumonia cases - Wuhan, China 2019-2020. China CDCWkly 2020;2(4):61 - 2. http://dx.doi.org/ 10.1016/j.bsheal.2020.01.003.

5. Daszak P, Olival KJ, Li HY. A strategy to prevent future epidemics similar to the 2019-nCoV outbreak. Biosaf Health 2020;2(1):6-8. http://dx.doi.org/10.1016/j.bsheal.2020.01.003.

6. Liu WJ, Wu GZ. Convincing the confidence to conquer COVID-19: from epidemiological intervention to laboratory investigation. Biosaf Health 2020;2(4):185 - 6. http://dx.doi.org/10.1016/j.bsheal.2020. 11.005 .

7. Huang BY, Tan WJ. SARS-CoV-2 variants: surveillance, evaluation, and challenges. Infect Dis Immun 2021;1(3):121 - 4. http://dx.doi.org/ 10.1097/ID9.0000000000000019.

8. Sakamoto H, Ishikane M, Ueda P. Seasonal influenza activity during the SARS-CoV-2 outbreak in Japan. JAMA 2020;323(19):1969 - 71. http://dx.doi.org/10.1001/jama.2020.6173.

9. Feng LZ, Zhang T, Wang Q, Xie YR, Peng ZB, Zheng JD, et al. Impact of COVID-19 outbreaks and interventions on influenza in China and the United States. Nat Commun 2021;12(1):3249. http:// dx.doi.org/10.1038/s41467-021-23440-1.

10. Soo RJJ, Chiew CJ, Ma S, Pung R, Lee V. Decreased influenza incidence under COVID-19 control measures, singapore. Emerg Infect Dis 2020;26(8):1933 - 5. http://dx.doi.org/10.3201/eid2608.201229.

11. Koutsakos M, Wheatley AK, Laurie K, Kent SJ, Rockman S. Influenza lineage extinction during the COVID-19 pandemic? Nat Rev Microbiol 2021. http://dx.doi.org/10.1038/s41579-021-00642-4.

12. Lai SJ, Ruktanonchai NW, Zhou LC, Prosper O, Luo W, Floyd JR, et al. Effect of non-pharmaceutical interventions for containing the COVID-19 outbreak in China. medRxiv 2020. http://dx.doi.org/ 10.1101/2020.03.03.20029843. 
13. World Organization for Animal Health (OIE). Update on avian influenza in animals (types $\mathrm{H} 5$ and $\mathrm{H} 7$ ). http://www.oie.int/animalhealth-in-the-world/update-on-avian-influenza/. [2021-10-29].

14. Lewis NS, Banyard AC, Whittard E, Karibayev T, Al Kafagi T, Chvala I, et al. Emergence and spread of novel H5N8, H5N5 and H5N1 clade 2.3.4.4 highly pathogenic avian influenza in 2020. Emerg Microbes Infect 2021;10(1):148-51. http://dx.doi.org/10.1080/22221751. 2021.1872355

15. Shi WF, Gao GF. Emerging H5N8 avian influenza viruses. Science 2021;372(6544):784 - 6. http://dx.doi.org/10.1126/science.abg6302.

16. Cui Y, Li Y, Li M, Zhao L, Wang D, Tian J, et al. Evolution and extensive reassortment of $\mathrm{H} 5$ influenza viruses isolated from wild birds in China over the past decade. Emerg Microbes Infect. 2020;9(1):1793803. http://dx.doi.org/10.1080/22221751.2020.1797542.

17. Pyankova OG, Susloparov IM, Moiseeva AA, Kolosova NP Onkhonova GS, Danilenko AV, et al. Isolation of clade 2.3.4.4b $\mathrm{A}(\mathrm{H} 5 \mathrm{~N} 8)$, a highly pathogenic avian influenza virus, from a worker during an outbreak on a poultry farm, Russia, December 2020. Euro Surveill 2021;26(24):2100439. http://dx.doi.org/10.2807/1560-7917. ES.2021.26.24.2100439.

18. World Health Organization. Avian influenza weekly update number 815. 2021. https://www.who.int/docs/default-source/wpro---documen ts/emergency/surveillance/avian-influenza/ai-20211022.pdf? sfvrsn=30d65594_176. [2021-10-29].

19. Xiao CK, Xu JN, Lan Y, Huang ZP, Zhou LJ, Guo YX, et al. Five independent cases of human infection with avian influenza H5N6 -
Sichuan province, China, 2021. China CDC Wkly 2021;3(36):751 - 6 . http://dx.doi.org/10.46234/ccdcw2021.187.

20. Wang QH, Chen H, Shi Y, Hughes AC, Liu WJ, Jiang JK, et al. Tracing the origins of SARS-CoV-2: lessons learned from the past. Cell Res 2021. http://dx.doi.org/10.1038/s41422-021-00575-w.

21. Tong YG, Liu WL, Liu PP, Liu WJ, Wang QH, Gao GF. The origins of viruses: discovery takes time, international resources, and cooperation. Lancet 2021;398(10309):1401 - 2. http://dx.doi.org/10. 1016/S0140-6736(21)02180-2.

22. Huang WJ, Li XY, Tan MJ, Cheng YH, Chen T, Wei HJ, et al Epidemiological and virological surveillance of seasonal influenza viruses - China, 2020-2021. China CDC Wkly 2021;3(44):918 - 22. http://dx.doi.org/10.46234/ccdcw2021.224.

23. Bi FY, Jiang LL, Huang LH, Wei JG, Pan XW, Ju Y, et al. Genetic characterization of two human cases infected with the avian influenza $\mathrm{A}$ (H5N6) viruses - Guangxi Zhuang Autonomous Region, China, 2021. China CDC Wkly 2021;3(44):923 - 8. http://dx.doi.org/10. 46234/ccdcw2021.199.

24. Yang JY, Yang L, Zhu WF, Wang DY, Shu YL. Epidemiological and genetic characteristics of the $\mathrm{H} 3$ subtype avian influenza viruses in China. China CDC Wkly 2021;3(44):929 - 36. http://dx.doi.org/ $10.46234 / \mathrm{ccdcw} 2021.225$.

25. Hammond A, Cozza V, Hirve S, Medina MJ, Pereyaslov D, Zhang WQ. Leveraging global influenza surveillance and response system for the COVID-19 pandemic response and beyond. China CDC Wkly 2021;3(44):937 - 40. http://dx.doi.org/10.46234/ccdcw2021.226. 